\title{
Impairment of nasal mucociliary clearance in woodworkers in the furniture industry
}

\author{
A. BLACK ${ }^{1}$, J. C. EVANS ${ }^{1}$, ESME H. HADFIELD ${ }^{2}$, R. G. MACBETH ${ }^{3}$, \\ A. MORGAN ${ }^{1}$, and M. WALSH ${ }^{1}$ \\ Health Physics and Medical Division, Atomic Energy Research Establishment, Harwell, \\ Didcot, Berks' ${ }^{1}$ Wycombe General Hospital, High Wycombe, Bucks ${ }^{2}$, and High Wycombe \\ and District Furniture Manufacturers Nasal Survey ${ }^{3}$
}

\begin{abstract}
Black, A., Evans, J. C., Hadfield, Esme H., Macbeth, R. G., Morgan, A., and Walsh, M. (1974). British Journal of Industrial Medicine, 31, 10-17. Impairment of nasal mucociliary clearance in woodworkers in the furniture industry. Measurements of mucociliary clearance from the anterior end of the middle turbinate were made using technetium-99m-labelled particles in nine woodworkers from the furniture industry and in 12 controls, none of whom had been occupationally exposed to wood dust. Clearance rates in the controls ranged from 1.9 to 18.5

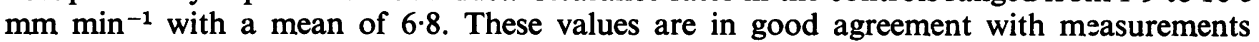
reported elsewhere for normal subjects. Only one of the woodworkers had a clearance rate which fell within the normal range and he had been occupationally exposed for the shortest period (6 years). In four woodworkers clearance was very slow $\left(<1 \mathrm{~mm} \mathrm{~min}^{-1}\right)$ and in three there was almost complete stasis. The results of this preliminary investigation suggest that nasal mucociliary function is significantly impaired in workers who have been exposed to wood dust in the furniture industry for more than 10 years.
\end{abstract}

It has been established that there is a significant correlation between adenocarcinoma of the ethmoid sinuses and occupational exposure in the furniture industry of Buckinghamshire and Oxfordshire (Acheson, Hadfield, and Macbeth, 1967; Acheson, Cowdell, Hadfield, and Macbeth, 1968; Hadfield, 1970). More recent work (Acheson, Cowdell, and Rang, 1972) has established that this correlation holds for other parts of England and Wales. It also appears that there is a similar incidence of adenocarcinoma in the furniture industries of Belgium (Debois, 1969) and France (Gignoux and Bernard, 1969).

In recent years, a survey has been carried out by one of us in the High Wycombe area in which the noses of woodworkers were examined at their place of work. It was noted that deposits of dust were frequently seen on the septum and particularly at the anterior ends of the middle turbinates. In view of this observation, it was decided to investigate nasal mucociliary function in woodworkers to determine if there was any impairment of dust clearance mechanisms.

Mucociliary transport rates have been studied by a number of workers following the application of dye particles, radioactive particles or solutions of radioactive material onto the nasal mucosa. The disadvantage of using dye is that frequent inspection of the pharynx is required, which is not necessary when radioactive tracer methods are employed. Proctor and Wagner (1965) were the first to use tracer methods in human subjects. They injected 20-30 $\mu \mathrm{Ci}$ of iodine-131 (as macroaggregated albumin) onto the nasal mucosa with a microsyringe and measured the transport rate, either from serial scans or with two fixed detectors. With this technique the labelled material spreads over quite a wide area of mucosa, and in more recent studies (Quinlan et al., 
1969; Andersen, Lundqvist, and Proctor, 1971) the movement of a single relatively large $(\sim 500 \mu \mathrm{m})$ resin bead, labelled with technetium-99m $\left({ }^{99 \mathrm{~m}} \mathrm{Tc}\right)$, has been followed after placement on the mucosa with an applicator.

In the present investigation, it was considered desirable to use particles with similar dimensions to airborne wood dust and also to avoid touching the mucosa during application. A technique was developed which enabled a microdrop (1-2 $\mu$ l) of a suspension of ${ }^{99 \mathrm{~m} T c}$-labelled polystyrene particles in physiological saline to be blown onto a predetermined position on the mucosa with considerable accuracy. It is considered unlikely that the rheological properties of the mucous film will be altered significantly by a drop of this size. Particles of $5 \mu \mathrm{m}$ diameter were selected as at that time it was anticipated that the airborne wood dust would have a mass median aerodynamic diameter (MMAD) in this region. Hounam, Black, and Walsh (1971) have shown that at normal breathing rates about $50 \%$ of $5 \mu \mathrm{m}$ spherical particles of unit density are deposited in the nose. However, a recent survey of the characteristics of airborne dust in a number of furniture factories in the High Wycombe area, carried out by Hounam and Williams (1974), showed that the MMAD of airborne wood dust is nearer $10 \mu \mathrm{m}$.

\section{Method}

\section{Subjects}

The controls were, with two exceptions, volunteers from the Health Physics and Medical Division at the Atomic Energy Research Establishment, Harwell. Their ages ranged from 31 to 69 with a mean of 48 years and none had been exposed occupationally to wood dust. Details of their ages, smoking habits, and the state of the mucosa are given in Table 1.

Woodworkers, all from a single factory in High Wycombe, selected on the basis of age and duration of exposure in the furniture industry, were approached and asked to take part in the investigation. Particulars of the nine who agreed to participate are given in Table 2. Their ages ranged from 48 to 66 with a mean of 56 years.

\section{Preparation of technetium-99m-labelled particles}

The test particles used in this investigation consisted of polystyrene spheres irreversibly labelled with ${ }^{99 \mathrm{~m}} \mathrm{Tc}$ (half-life 6 hours). They were prepared with a spinning disc aerosol generator using the technique described by Few, Short, and Thomson (1970). The rotational speed of the disc was adjusted until the solid particles produced had a diameter of $5 \mu \mathrm{m}$. The particles were collected in a water impinger, washed by centrifuging, and finally resuspended in physiological saline just before administration. Tests on suspensions of particles in saline showed that less than $1 \%$ of the radioactivity was leached per day.

\section{Administration of labelled particles}

The subject's nose was examined and the condition of the mucosa noted. A mark was made on the right cheek at a point corresponding to the centre of the anterior end of the middle turbinate in the larger passage. As the turbinates could be observed only with monocular vision, the fact that the lacrimal sac lies just anterior to the anterior end of the middle turbinate was utilized in positioning the mark. The subject then sat in a dentist's chair which was adjusted so that the mark was coaxial with the collimator of detector $\mathbf{C}$ (see below). To facilitate accurate repositioning of the subject following administration, arrows from projection torches were focused on small adherent paper discs attached to the nose and cheek.

The apparatus used for the administration of the particle suspension consisted of a $0.01 \mathrm{ml}$ glass pipette

TABLE 1

CONTROLS

\begin{tabular}{|c|c|c|c|c|c|c|c|}
\hline Ref. & Age & Smoking habits & $\begin{array}{l}\text { State of } \\
\text { mucosa }\end{array}$ & $\begin{array}{c}\text { Temperature } \\
\left({ }^{\circ} \mathrm{C}\right)\end{array}$ & $\begin{array}{c}\text { Relative } \\
\text { humidity } \\
(\%)\end{array}$ & $\begin{array}{l}\text { Half-time of } \\
\text { clearance } \\
(\text { min })\end{array}$ & $\begin{array}{c}\text { Rate of } \\
\text { movement } \\
\left(\mathrm{mm} \mathrm{min}^{-1}\right)\end{array}$ \\
\hline $\begin{array}{l}\text { C8 } \\
\text { C9 } \\
\text { C10 } \\
\text { C11 } \\
\text { C12 }\end{array}$ & $\begin{array}{l}45 \\
47 \\
\\
50 \\
56 \\
56 \\
58 \\
69\end{array}$ & $\begin{array}{l}\text { Moderate smol:sr } \\
\text { Non-smoker } \\
\text { Almost non-smoker } \\
\text { Non-smoker } \\
\text { Non-smoker } \\
\text { Non-smoker } \\
\text { Pipe smoker } \\
\text { Moderate smoker } \\
\text { Non-smoker } \\
\text { Non-smoker } \\
\text { Non-smoker } \\
\text { Non-smoker }\end{array}$ & $\begin{array}{l}\text { Moist } \\
\text { Moist } \\
\text { Wet } \\
\text { Moist } \\
\text { Moist } \\
\text { Moist } \\
\text { Moist } \\
\text { Normal } \\
\text { Normal } \\
\text { Normal } \\
\text { Normal } \\
\text { Normal } \\
\text { Normal } \\
\text { Moist } \\
\text { Moist } \\
\text { Normal }\end{array}$ & $\begin{array}{l}23 \\
23 \\
24 \\
24 \\
22 \\
22 \\
23 \\
24 \\
24 \\
23 \\
22 \\
21 \\
23 \\
23 \\
23 \\
24\end{array}$ & $\begin{array}{l}36 \\
33 \\
38 \\
37 \\
49 \\
46 \\
47 \\
37 \\
37 \\
47 \\
50 \\
56 \\
33 \\
39 \\
36 \\
38\end{array}$ & $\begin{array}{l}4 \cdot 1 \\
2 \cdot 5 \\
1 \cdot 7 \\
6 \cdot 0 \\
6 \cdot 1 \\
3 \cdot 0 \\
2 \cdot 1 \\
6 \cdot 6 \\
1 \cdot 4 \\
1 \cdot 4 \\
1 \cdot 6 \\
5 \cdot 7 \\
1 \cdot 4 \\
2 \cdot 6 \\
7 \cdot 3 \\
1 \cdot 5\end{array}$ & $\begin{array}{r}2 \cdot 6 \\
9 \cdot 2 \\
6 \cdot 2 \\
4 \cdot 6 \\
2 \cdot 7 \\
4 \cdot 6 \\
7 \cdot 4 \\
4 \cdot 1 \\
7 \cdot 4 \\
12 \cdot 3 \\
7 \cdot 4 \\
1 \cdot 9 \\
18 \cdot 5 \\
8 \cdot 5 \\
2 \cdot 3 \\
9 \cdot 2\end{array}$ \\
\hline
\end{tabular}


TABLE 2

WORKERS IN THE FURNITURE INDUSTRY

\begin{tabular}{|c|c|c|c|c|c|c|c|c|c|c|}
\hline Ref. & Age & $\begin{array}{c}\text { Years } \\
\text { in } \\
\text { industry }\end{array}$ & $\begin{array}{c}\text { Smoking } \\
\text { habits }\end{array}$ & $\begin{array}{l}\text { Appearance } \\
\text { of mucosa }\end{array}$ & Cytology & $\begin{array}{c}\text { Dust } \\
\text { present }\end{array}$ & $\begin{array}{c}\text { Temper- } \\
\text { ature } \\
\left({ }^{\circ} \mathrm{C}\right)\end{array}$ & $\begin{array}{c}\text { Relative } \\
\text { humidity } \\
(\%)\end{array} \mid$ & $\begin{array}{c}\text { Half-time } \\
\text { of clearance } \\
\text { (min) }\end{array}$ & $\begin{array}{c}\text { Rate of } \\
\text { movement } \\
\left(\mathrm{mm} \mathrm{min}^{-1}\right)\end{array}$ \\
\hline W1 & 48 & 6 & Non-smoker & Normal & $\begin{array}{l}\text { Normal columnar } \\
\text { epithelium }\end{array}$ & - & 19 & 62 & $4 \cdot 3$ & $2 \cdot 7$ \\
\hline W2 & 50 & 16 & Non-smoker & Normal & $\begin{array}{l}\text { Normal columnar } \\
\text { epithelium }\end{array}$ & - & 21 & 55 & 30 & 一 \\
\hline W3 & 53 & 12 & $\begin{array}{l}\text { Almost } \\
\text { non-smoker }\end{array}$ & Normal & $\begin{array}{l}\text { Normal columnar } \\
\text { epithelium }\end{array}$ & - & 20 & 62 & $>60$ & - \\
\hline W4 & 54 & 12 & Smoker & Dry red & $\begin{array}{l}\text { Normal + occa- } \\
\text { sional squamous } \\
\text { cells }\end{array}$ & - & 20 & 58 & Stasis & - \\
\hline W5 & 54 & 25 & $\begin{array}{l}\text { Light } \\
\text { smoker. }\end{array}$ & Rather dry & $\begin{array}{l}\text { Normal + } \\
\text { cuboidal cells }\end{array}$ & - & 20 & 58 & Stasis & - \\
\hline W6 & 58 & 26 & Non-smoker & Dry & $\begin{array}{l}\text { Normal }+ \\
\text { squamous meta- } \\
\text { plastic cells }\end{array}$ & + & 19 & 61 & 46 & - \\
\hline W7 & 60 & 27 & Snuffer & Wet boggy & $\begin{array}{l}\text { Normal + } \\
\text { squamous meta- } \\
\text { plastic cells }\end{array}$ & Snuff & 21 & 59 & Stasis & - \\
\hline W8 & 63 & 15 & Smoker & Pale & $\begin{array}{l}\text { Normal + less } \\
\text { mature 'basal' cells }\end{array}$ & + & 22 & 49 & $>60$ & - \\
\hline W9 & 66 & 15 & $\begin{array}{l}\text { Moderate } \\
\text { smoker }\end{array}$ & Moist & $\begin{array}{l}\text { Normal }+ \\
\text { squamous meta- } \\
\text { plastic cells }\end{array}$ & - & 20 & 61 & $10 \cdot 2$ & $1 \cdot 0$ \\
\hline
\end{tabular}

inserted in a brass $\mathrm{T}$ piece, one arm of which was connected via a solenoid operated valve to a small reservoir of compressed air at a pressure of 12 inches of water. A small electric light bulb was located in the other arm so that the pipette acted as a light guide, producing a spot with diameter $1 \mathrm{~mm}$ at a distance of $1 \mathrm{~cm}$ from the tip.

To administer the particles a small volume $(1-2 \mu \mathrm{l})$ of a suspension of labelled particles was drawn into the tip of the pipette by capillary action. This volume of suspension contained about 50000 particles. After surplus material had been wiped from the tip, the pipette was inserted in the selected nasal passage using a speculum to dilate the vestibule. With the spot of light to act as a guide, the pipette was aimed at the centre of the anterior end of the middle turbinate and operation of the solenoid valve blew the droplet onto the mucosa. There was little spread of material on impact and in no case was the subject aware of any sensation when the particles were administered. A red dye (Biebrich Scarlet R) incorporated in the particles enabled the accuracy of administration to be checked visually. Measurements of radioactivity were always started within a minute of administration.

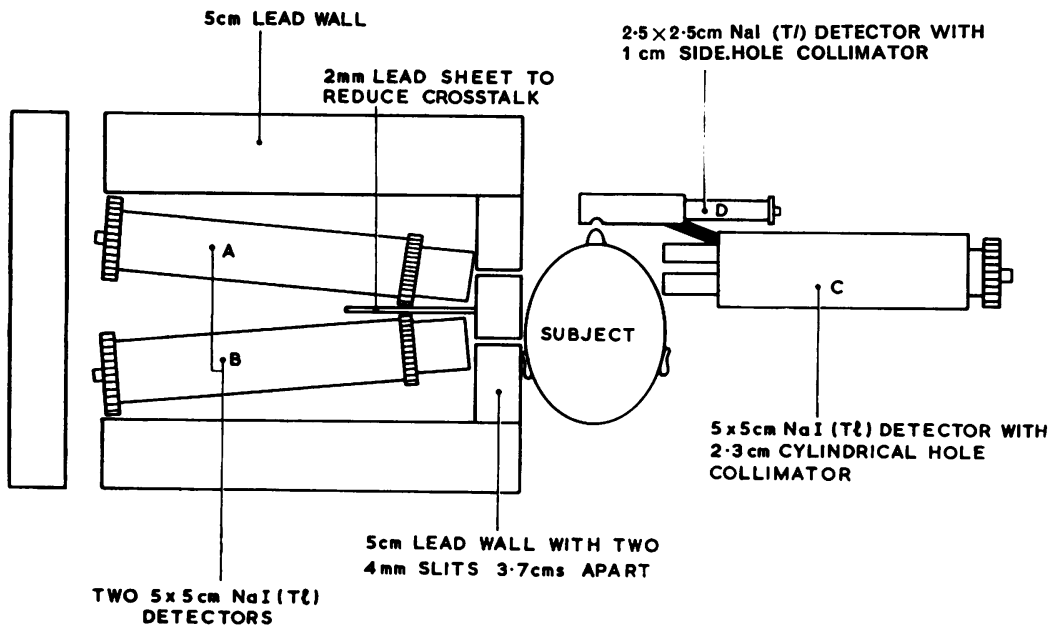

FIG. 1. Arrangement of detectors relative to subject (seen from above). 
Measurement of particle clearance

Following administration, the movement of particles was monitored by an array of four $\mathrm{NaI}(\mathrm{Tl})$ detectors shown diagrammatically in Figure 1. On the left of the subject's head, two $5 \times 5 \mathrm{~cm}$ detectors (A and B) were located behind vertical slit collimators, each of dimensions $0.4 \times 6.5 \mathrm{~cm}$. The distance between the centres of the slits was $3.7 \mathrm{~cm}$. To achieve maximum counting efficiency, the detectors were angled as shown (Figure 1). The cross talk between the detectors was insignificant and they were shielded by $5 \mathrm{~cm}$ of lead which reduced their background to about $30 \mathrm{cpm}$.

$A$ third detector (C), the same size as $A$ and $B$, was located on the right of the subject's head. Attached to the face of the crystal was a cylindrical lead collimator with a parallel sided hole $2 \cdot 3 \mathrm{~cm}$ in diameter and $5 \mathrm{~cm}$ long. The axis of this collimator corresponded to a position $1.8 \mathrm{~cm}$ in front of and $3.5 \mathrm{~cm}$ above the lower end of the anterior slit. It contained a small $45^{\circ}$ mirror so that a light beam entering a hole in the side was directed along its axis. This facilitated alignment of this detector with the mark on the subject's cheek.

The fourth detector (D) consisted of a $2.5 \times 2.5 \mathrm{~cm}$ crystal in a cylindrical lead shield with a $1 \mathrm{~cm}$ diameter hole cut in one side. The detector was positioned so that

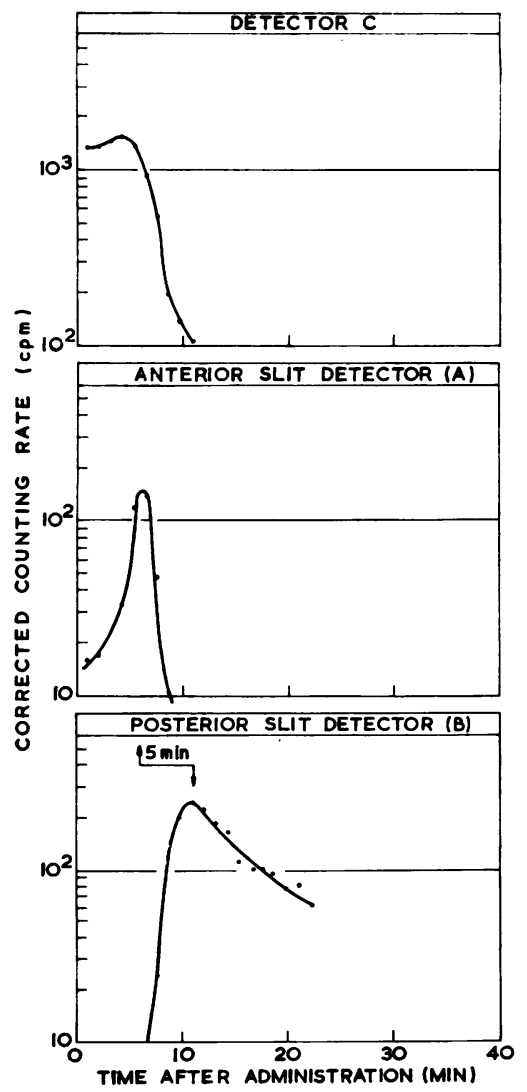

FIG. 2. Corrected counting rates from detectors A, B, and $\mathrm{C}$ during measurements on subject $\mathrm{C7}$. the hole was just in front of the tip of the subject's nose. Detectors $\mathrm{C}$ and $\mathrm{D}$ were linked and could be retracted along their axes to facilitate access to the chair.

Each detector was connected to a linear amplifying system and scaler. The counts accumulating in one minute intervals were printed out and the counters were restarted automatically. The outputs of detectors $A$ and $B$ were also connected via ratemeters to a two-channel pen recorder so that a visual record of counting rates at the anterior and posterior slits was available during the course of each experiment.

\section{Radiological dose}

The average amount of ${ }^{99 \mathrm{~m}} \mathrm{Tc}$ administered for each measurement was $0.7 \mu \mathrm{Ci}$, which is within the limit approved by the Medical Research Council Isotope Advisory Committee. The radiation doses involved were extremely small. For subjects with clearance rates within the normal range, the upper large intestine is the critical organ, and in no case did the dose exceed 1 mrem. In woodworkers with very slow clearance or stasis, the nasal mucosa is the critical organ, and for the three subjects with stasis, the average dose to the mucosa was about 30 mrem. The safety of the procedure was explained to the subjects.

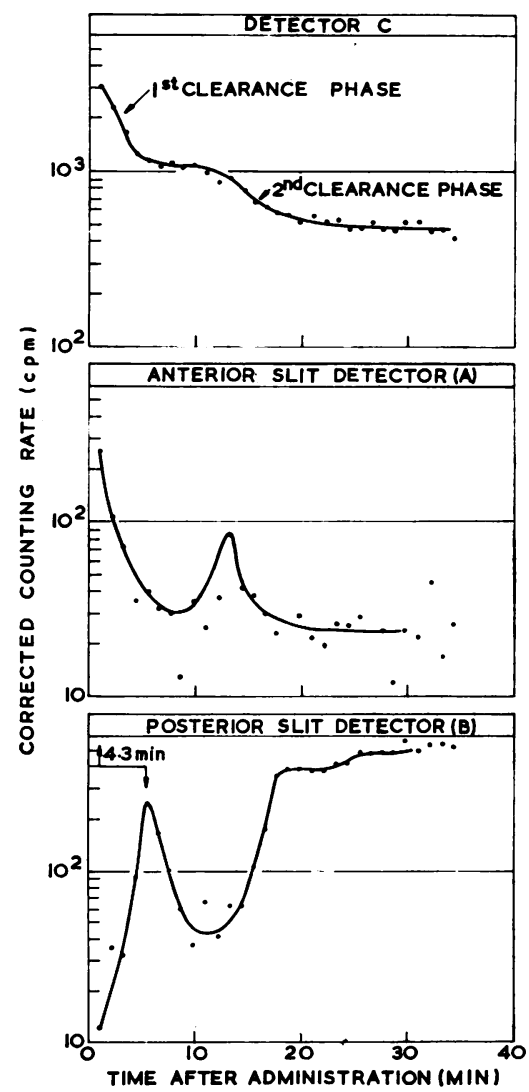

FIG. 3. Corrected counting rates from detectors A, B, and $\mathrm{C}$ during measurements on subject $\mathrm{C10}$. 


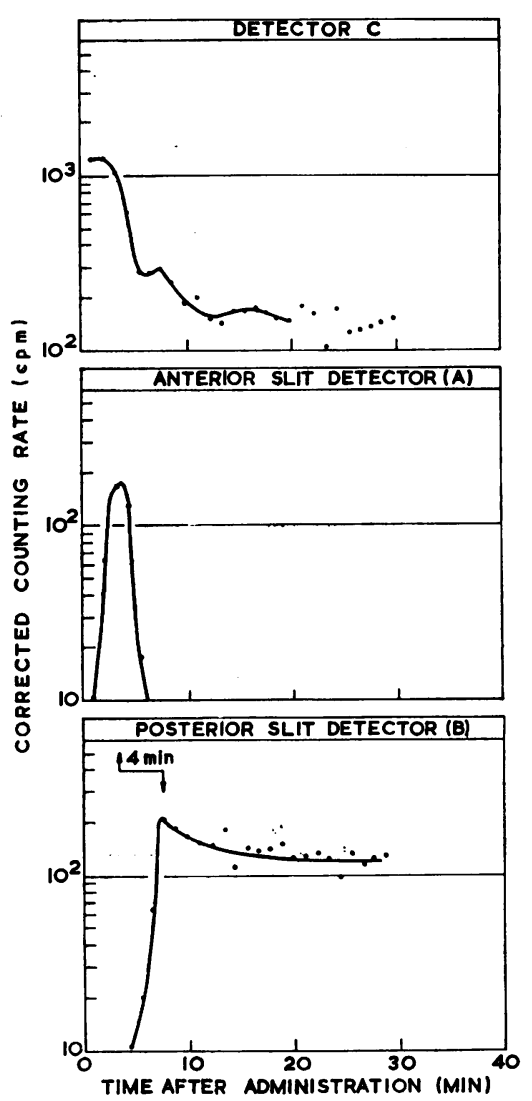

FG. 4. Corrected counting rates from detectors A, B, and $\mathrm{C}$ during measurements on subject $\mathrm{C} 12$.

\section{Results}

\section{Controls}

In all the controls there was fairly rapid movement of particles from the site of deposition. The corrected counting rates for detectors $\mathrm{A}, \mathrm{B}$, and $\mathrm{C}$ during experiments on subjects $\mathrm{C} 7, \mathrm{C10}$, and $\mathrm{C12}$ are shown in Figures 2, 3, and 4 respectively.

During measurements on the controls, the counting rate from detector $A$ behind the anterior slit reached a maximum during the first 10 minutes and then declined fairly rapidly. The time taken to reach this maximum clearly depends upon the position of the slit relative to the site of deposition, as well as on the rate of movement of particles. The counting rate from detector B behind the posterior slit generally started to increase a few minutes later. In some subjects this increase was followed by a decline and in others by a further gradual increase. One subject (Fig. 3) demonstrated both patterns. These observations indicate that in some subjects, material removed from the anterior end of the middle turbinate tends to accumulate at the back of the nasal passages before being swallowed. It is also possible that at this point material is moving along or obliquely across the slit as it travels down the palate or lateral wall of the nasopharynx. All the controls exhibited clearly defined peaks in counting rate at both the anterior and posterior slits, and it was possible to derive rates of clearance from the time interval between them. Values obtained in this way are included in Table 1.

Typically, the counting rate from detector C declined over the first 10 minutes. Occasionally there was a slight initial rise in counting rate which could be due either to inaccurate alignment of the detector with respect to the site of administration or to lateral movement of particles on the turbinate towards the detector. In some cases the counting rate declined rapidly to background level, showing that all the particles had been cleared, while in others only part of the material was removed in the initial phase. Some subjects (Fig. 3) showed evidence of two distinct clearance phases, probably due to dispersion of the droplet and fragments following different routes on the turbinate. The corrected counting rates for this detector (normalized to an initial rate of $2000 \mathrm{cpm}$ ) are shown in Figure 5 . In all subjects the counting rate of detector $D$ declined steadily. In no case was there any increase which could be attributed to forward clearance.

\section{Woodworkers}

The clearance of labelled particles was generally much slower in the woodworkers than in the controls. For this reason, well defined peaks in counting rate from detectors $A$ and $B$ were observed in only two subjects. Although it was not possible to derive clearance rates for the other seven woodworkers by this method, information could be obtained from the counting rates from detector $\mathrm{C}$ (Fig. 6). These showed that in four there was very slow clearance, and in the other three no discernible clearance at all over a period of $\mathbf{3 0}$ minutes.

\section{Discussion}

Measurements of clearance on woodworkers were performed in the General Hospital at High Wycombe. Two of the controls were measured at High Wycombe and the remainder at the Atomic Energy Research Establishment, Harwell. Measurements of temperature and humidity were made during each investigation and are listed in Tables 1 and 2. During the measurements at Harwell, the temperature was slightly higher and the humidity slightly lower than at High Wycombe. It is not considered likely, however, that variations within the observed range had any significant effect on clearance rates.

Measurements of nasal mucociliary clearance 


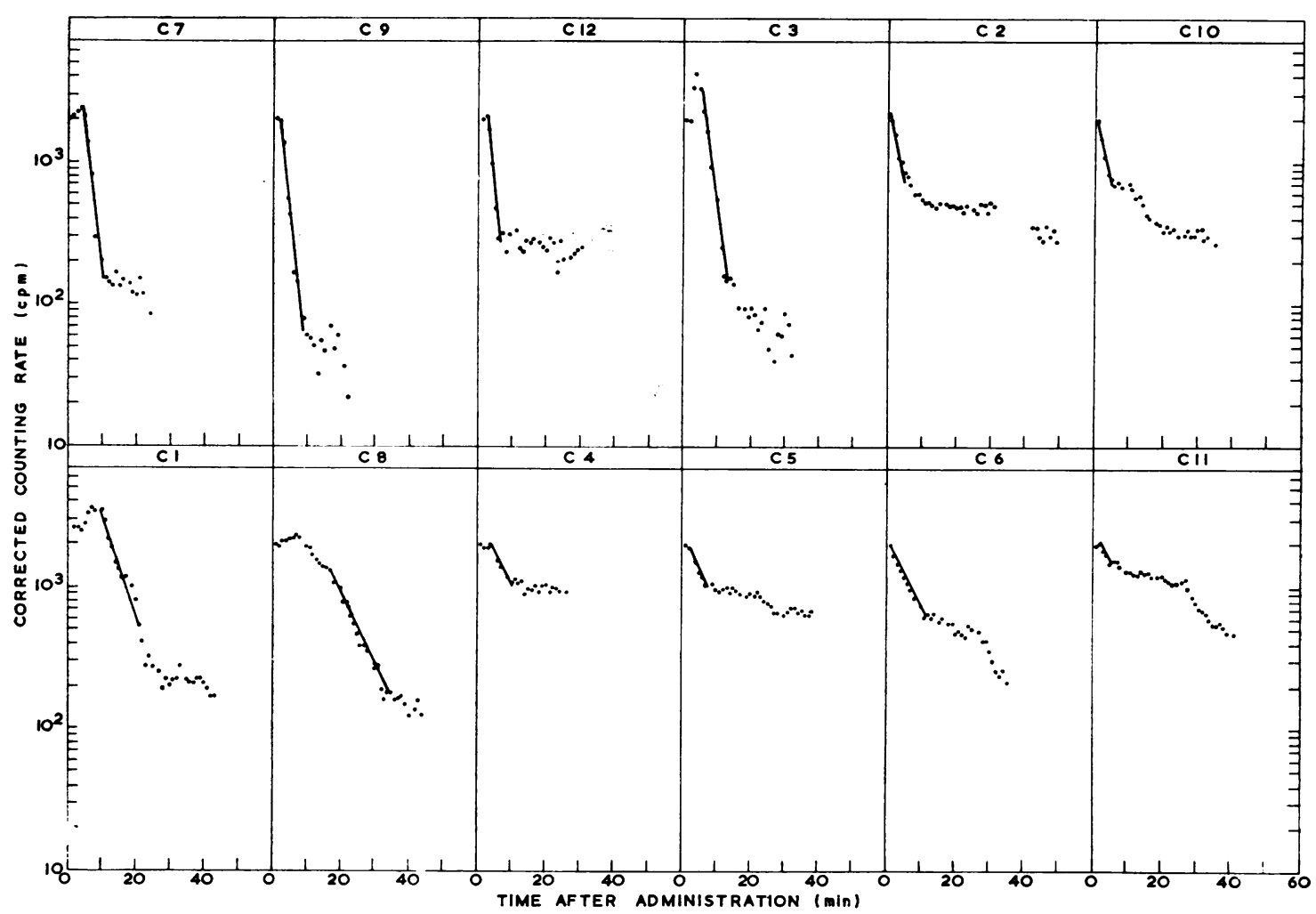

FIG. 5. Corrected counting rate from detector $C$ (normalized to an initial value of $2000 \mathrm{cpm}$ ) $v$ time after administration. Results for controls.

rates in normal subjects have been reported by a number of workers. The average rates of movement reported in the various studies fall in the range 5-10 $\mathrm{mm} \mathrm{min}^{-1}$ although the rates in individual subjects varied from $<1$ to $100 \mathrm{~mm} \mathrm{~min}^{-1}$. For example, Andersen et al. (1971) were able to classify their subjects into three groups-32 who had uninterrupted particle movement, 14 who had a retardation after an initial normal flow, and 10 who had either a consistent slow movement or stasis. The results of a number of investigations are sum- marized in Table 3 which includes the results for the controls used in the present investigation. This shows that both the average rate of clearance and the range measured in the controls correspond well with the results of other workers. Repeat measurements were made on subjects $\mathrm{C} 5$ and $\mathrm{C} 7$ on different days over a period of about a month. The results (see Table 1) indicate that clearance rates do vary from day to day. From the limited number of results, it does not appear that there is any deterioration in mucociliary function below the age of 70 in

TABLE 3

Rate of Mucociliary Clearance in the Human Nose

\begin{tabular}{|c|c|c|c|c|}
\hline \multirow{2}{*}{ Author } & \multirow{2}{*}{ Tracer } & \multirow{2}{*}{$\begin{array}{c}\text { No. of } \\
\text { subjects }\end{array}$} & \multicolumn{2}{|c|}{ Rate of movement $\left(\mathrm{mm} \mathrm{min}^{-1}\right)$} \\
\hline & & & Range & Mean \\
\hline $\begin{array}{l}\text { Proctor and Wagner (1965) } \\
\text { Bang et al. (1967) } \\
\text { Andersen et al. (1971) } \\
\text { Quinlan } \text { et al. }(1969) \\
\text { This work }\end{array}$ & 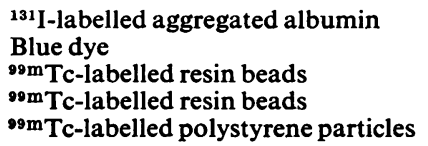 & $\begin{array}{l}24 \\
24 \\
32 \\
46 \\
12\end{array}$ & $\begin{array}{c}3-9 \\
4 \cdot 9-100 \\
2-24 \\
0-15 \\
1 \cdot 9-18 \cdot 5\end{array}$ & $\begin{array}{l}6 \\
10 \cdot 4 \\
8 \cdot 4 \\
7 \\
6 \cdot 8\end{array}$ \\
\hline
\end{tabular}




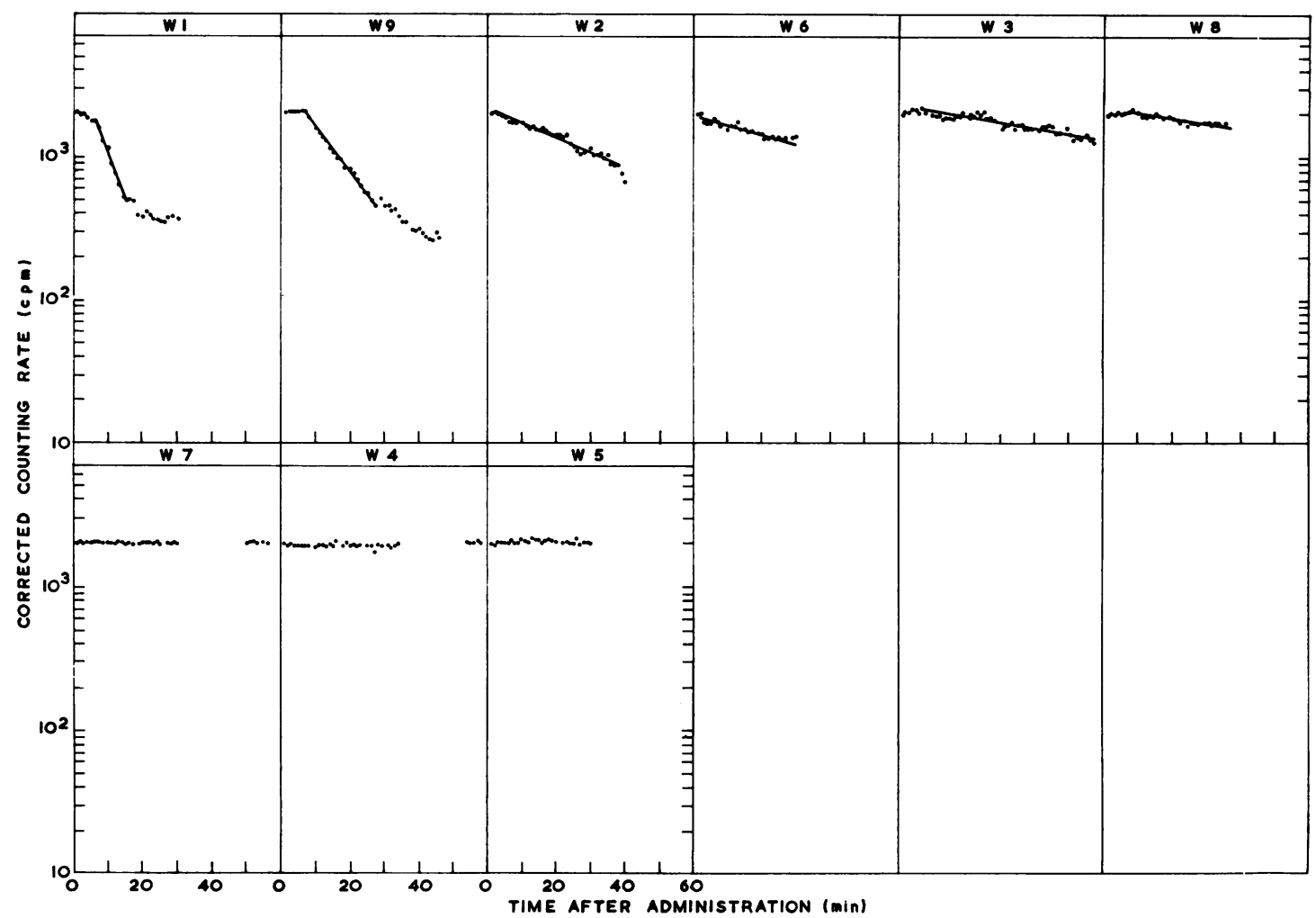

FIG. 6. Corrected counting rate from detector $C$ (normalized to an initial value of $2000 \mathrm{cpm}$ ) $v$ time after administration. Results for woodworkers.

non-smokers. There are insufficient data for any conclusions to be drawn regarding the effect of cigarette smoking. However, the results of Bang, Mukherjee, and Bang (1967) and of Quinlan et al. (1969) suggest that nasal mucociliary function is not radically impaired in smokers.

In most of the woodworkers, clearance was too slow to derive a value for the rate of movement from observations of counting rates at the two slits. To quantify the rate in subjects with restricted clearance, single exponential expressions were fitted to the corrected counting rates from detector $\mathrm{C}$ for the period over which it was changing most rapidly (Figs. 5 and 6). In this way a half-time of clearance $\left(t_{\frac{1}{2}}\right)$ was obtained for all subjects, except those in whom there was either very slow clearance or stasis. Values of $t_{\frac{1}{2}}$ obtained in this way are listed in Tables 1 and 2. In Fig. 7 measurements of clearance rates are plotted against the reciprocals of the corresponding values of $t_{t}$ for subjects for whom both values are available. While there is a reasonable correlation $(r=0.80)$ there is some scatter in the results which might be expected, as $t_{\frac{1}{t}}$ represents clearance from the site of deposition, while the rate

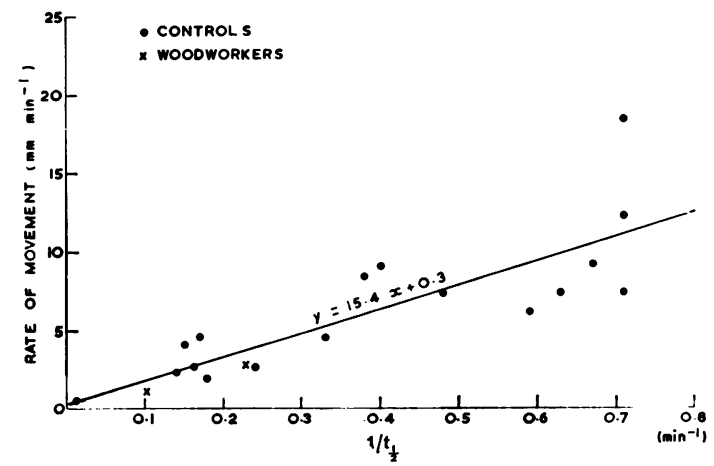

FIG. 7. Correlation between rate of movement of particles and the reciprocal of the half-time of clearance.

of movement is derived from the time taken to traverse the distance between the slits, not necessarily by the identical route in all cases. Clearly, measurements of $t_{\frac{1}{2}}$ are particularly useful in cases where the rate of clearance is too slow $(<2 \mathrm{~mm}$ 
$\min ^{-1}$ ) to be determined accurately from the counting rates at the anterior and posterior slits.

Because of the slow movement of particles, measurements of clearance rates were possible in only two of the woodworkers. In one, the rate was $2.7 \mathrm{~mm} \mathrm{~min} \mathrm{~m}^{-1}$, which is within the range of values measured in the controls. This worker was the youngest of the nine and had worked in the furniture industry for only six years. In the other, the oldest of the woodworkers, who had been in the industry for 15 years, the rate was $1 \mathrm{~mm} \mathrm{~min}^{-1}$. Although it was not possible to measure clearance rates in the other seven woodworkers, information on clearance could be derived from measurements at the site of deposition with detector $\mathrm{C}$. Three of the seven showed no significant clearance over a period of 30-60 minutes, and two had very slow clearance $\left(t_{\frac{1}{2}}>1\right.$ hour). The values for $t_{\frac{1}{2}}$ are included in Table 2 and, using this criterion also, only one of the woodworkers is within the range of the controls.

As well as noting the appearance of the nasal mucosa, smears were taken from the noses of woodworkers at the termination of clearance measurements. The appearance of the mucosa and the results of cytological examination of the smears are described in Table 2. The mucosa of three woodworkers was dry in appearance, and in the snuff taker it was described as wet and boggy, which is characteristic. Squamous cells were identified in smears from one woodworker and metaplastic cells in smears from three others.

\section{Conclusions}

It appears from the results of this limited investigation that exposure to wood dust in the furniture industry for 10 years or more can impair mucociliary clearance at the anterior end of the middle turbinate. Clearly, a more detailed study would be required to relate cause and effect more precisely. The fact that deposits of dust are frequently seen at this site in woodworkers suggests that impairment may be quite general.

The significance of these observations with regard to the aetiology of nasal adenocarcinoma in woodworkers is of interest. Hadfield and Macbeth (1971) have suggested that fine wood dust, or soluble constituents derived therefrom, may find its way into the mucous glands of workers with impaired clearance.

Examination of particles of airborne wood dust, sampled in furniture factories in the High Wycombe area, with the scanning electron microscope (Hounam and Williams, 1974) showed that they are generally fibrous or flaky in character and have a high surface area to volume ratio which could facilitate the leaching of soluble toxic constituents. If certain types of wood contain soluble carcinogens, then in workers with impaired clearance, certain regions of the mucosa will be subjected to higher concentrations than in subjects with normal clearance. This may account for the relatively high incidence of squamous metaplasia in the noses of woodworkers.

This investigation was supported by grants from the Oxford Regional Hospital Board and the Medical Research Council. The authors wish to thank Mr. L. Ercolani and members of his staff for their co-operation in this study and the Secretary of the Wycombe General Hospital for providing accommodation. They wish to acknowledge the technical assistance of Mr. D. R. Belcher.

\section{References}

Acheson, E. D., Cowdell, R. H., Hadfield, E., and Macbeth, R. G. (1968). Nasal cancer in woodworkers in the furniture industry. British Medical Journal, 2, 587-597.

,-- , and Rang, E. (1972). Adenocarcinoma of the nasal cavity and sinuses in England and Wales. British Journal of Industrial Medicine, 29, 21-30.

_, Hadfield, E. H., and Macbeth, R. G. (1967). Carcinoma of the nasal cavity and accessory sinuses in woodworkers. Lancet, 1, 311-312.

Andersen, I., Lundqvist, G. R., and Proctor, D. F. (1971). Human nasal mucosal function in a controlled climate. Archives of Environmental Health, 23, 408-420.

Bang, B. G., Mukherjee, A. L., and Bang, F. B. (1967). Human nasal mucus flow rates. Johns Hopkins Medical Journal, 121, 38-48.

Debois, J. M. (1969). Tumoren van de neusholte bij houtbewerkers. Tijdschrift voor Geneeskunde, 2, 92.

Few, J. D., Short, M. D., and Thomson, M. L. (1970). Preparation of ${ }^{99 \mathrm{~m} T c}$ labelled particles for aerosol studies. Radiochemical Radioanalytical Letters, 5, 275-277.

Gignoux, M. and Bernard, P. (1969). Tumeurs malignes de l'ethmoide chez les travailleurs du bois. Journal Médecine de Lyon, 50, 731-736.

Hadfield, E. H. (1970). A study of adenocarcinoma of the paranasal sinuses in woodworkers in the furniture industry. Annals of the Royal College of Surgeons, 46, 301-319.

- and Macbeth, R. G. (1971). Adenocarcinoma of ethmoids in furniture workers. Annals of Otology Rhinology and Laryngology, 80, 699-703.

Hounam, R. F., Black, A., and Walsh, M. (1971). The deposition of aerosol particles in the nasopharyngeal region of the human respiratory tract. Aerosol Science, 2, 47-61. - and Williams, J. (1974). Levels of airborne dust in furniture making factories in the High Wycombe area. British Journal Industrial Medicine, 31, 1-9.

Proctor, D. F. and Wagner, H. N. (1965). Clearance of particles from the human nose. Archives of Environmental Health, 11, 366-371.

Quinlan, M. F. Salman, S. D., Swift, D. L., Wagner, H. N., and Proctor, D. F. (1969). Measurement of mucociliary function in man. American Review of Respiratory Diseases, 99, 13-23.

Received for publication May 21, 1973

Accepted for publication July 19, 1973 